\title{
ASSESSING THE INSTITUTIONAL AND FINANCIAL FACTORS OF THE IFRS FOUNDATION MANAGEMENT FROM THE PERSPECTIVE OF THE EURASIAN ECONOMIC UNION
}

Mikhail V. RODCHENKOV

Lomonosov Moscow State University,
Moscow, Russian Federation
M.Rodchenkov@gmail.com
https://orcid.org/0000-0002-6938-2313

Article history:

Article No. 533/2021

Received 27 Sept 2021

Received in revised form

11 October 2021

Accepted 30 Oct 2021

Available online

27 December 2021

JEL: F53, F55, F65, G15, M49

\section{Keywords:}

IFRS Foundation, EEU, globalization, accounting process, management

\section{Abstract}

Subject. This article explores the impact of the modern institutional and financial structure of the IFRS Foundation on the quality and functionality of the international financial reporting standards, as the main instruments of globalization of the financial and economic sphere, caused by insufficiency in the management of the IFRS Foundation.

Objectives. The article aims to identify the reasons for the growth of risk factors in the IFRS Foundation's activities caused by its institutional and financial structure, taking into account the previously identified problems of the IFRS Foundation management, assess the position of the Eurasian Economic Union (EEU) in the IFRS management system, and develop practical proposals to minimize the identified risks.

Methods. For the study, I used a comparative analysis.

Results. The article finds that the institutional and financial structure of the IFRS Foundation is characterized by disproportion of the current national, sectoral, and financial representation in the Foundation's management bodies. This creates risks of inharmonious development of IFRS and confirms the ongoing pendency of the Foundation's unresolved management problems previously identified. The current position of the EEU is characterized by a significant imbalance between functional and financial representations in the Foundation's management system. To reduce such risks, the article proposes to diversify the industry representation, and introduce financial participation coefficients and national representation into the practice of the Foundation's management, based on a transparent and understandable algorithm using public data.

Conclusions. The formulated proposals can be useful for the authorized federal governing bodies of the Russian Federation and the EEU governing bodies when developing growth strategies in the field of accounting and reporting, to improve international standards, and protect the national economic interests of the EEU countries in the course of the IFRS Foundation's activities under present-day conditions.

(c) Publishing house FINANCE and CREDIT, 2021 
The editor-in-charge of this article was Andrey V. Bazhanov

Please cite this article as: Rodchenkov M.V. Assessing the Institutional and Financial Factors of the IFRS Foundation Management from the Perspective of the Eurasian Economic Union. Digest Finance, 2021 , vol. 26 , iss. 4 , pp. $470-482$.

https://doi.org/10.24891/df.26.4.470

\section{Introduction}

The International Financial Reporting Standards (IFRS) have been applied in 140 countries for several years ${ }^{1}$. These standards are a prerequisite for admission to most major capital markets. It is important that the IFRS, as a market mechanism element, are acting in the interests of all users.

The purpose of this study is to identify risk drivers in the activities of the IFRS Foundation, while accounting for the growing gap between developing and predominant economic regions, increasing political tension, industrial specifics, modern accounting methodology, functional currencies, and inflation. The methodology is based on a comparative analysis of the content of the standards and open-source quantitative and qualitative data on the regulatory bodies of the IFRS Foundation.

The study revealed growing imbalances regarding industrial specifics, the structure of financing, and subsequently, the risk of creating regional standards, as well as the need to increase the participation of the member countries of the Eurasian Economic Union $(\mathrm{EEU})^{2}$ in the IFRS Foundation's activities.

\section{Literature review}

There is a widespread consensus among economists that the growing role of global standards significantly affects the degree of confidence of market participants' financial reporting. However, the assessment of this impact is varied [1, 2].

Additionally, the ambivalence in assessing the usefulness of the IFRS is influenced by various factors. Extant studies of the qualitative characteristics of the IFRS Foundation and the implementation of IFRS, both with regard to its initiators or the 'founding fathers' [3], and the national systems that have joined this community, including those from the post-socialist camp [4], point to an initial lack of consensus of views on and functionality of the standards and their interpretations [5,6]. At the same time, the importance of non-governmental organizations in developing and implementing international standards is highlighted, as well as the significance of institutional factors in the IFRS management

\footnotetext{
"For the source article, please refer to: Родченков М.В. Оценка институционального и финансового факторов управления системой международных стандартов финансовой отчетности с позиции Евразийского экономического союза // Финансы и кредит. 2021. Т. 27. Вып. 9. С. 2139-2157. URL: https://doi.org/10.24891/fc.27.9.2139

${ }^{1}$ IFRS Foundation. Who We Are. URL: https://ifrs.org/about-us/who-we-are/

${ }^{2}$ EEU. Eurasian Economic Union. URL: http://eaeunion.org/?lang=en\#about
} 
system. Attention is drawn to the impetus for the dissemination of IFRS to provide a consensus of interests and the methodological commitment of representation of the Anglo-Saxon participants and the continental accounting schools [3], which form a field of discussions within the modern IFRS Foundation up to now.

A parallel work flow highlights a poor consideration of contextual factors, which determine the evolution of a company's vertical structure within the industry [7] reflects the disregard of the specifics of national legal requirements and of the political involvement of companies [8, 9], as significant factors for evaluating the functionality of international standards. While some aspects encourage firms to be less open with information, others have the opposite effect, encouraging them to be more transparent. The displacement of the boundaries of the zones of the marked effects is determined by the quality of the human resources involved in these processes [9].

The instability of such a boundary reinforces the criticism of financial reporting, exhibited by the increased frequency and complexity of the reporting $[10,11]$ and by the reduced ability to reflect the company's performance, among others [12]. As a result of implementing the IFRS, English-speaking countries (such as Canada) have benefited more than other countries, wherein significant differences between the IFRS and national standards have been identified [13].

Moreover, researchers have noted the increasing influence of new factors, including the increased importance of social networks as channels for social management of the professional community [14], and the awareness of the need for comprehensive participation by the legal institutions of the state in the development of IFRS, the introduction of new management mechanisms and market control systems [15], as well as the right combination of political and economic professional decisions [16]. Furthermore, these new factors are prevalent against the backdrop of increasing uncertainty in the international environment and the use of the IFRS by China and the United States as an integral part of tools that are of a political and economic nature [17]. The range and power of influence in the management and development of international standards and their interpretations, as well as the effectiveness of China's representatives in this process, have significantly changed with the inclusion of its representatives in the IFRS Foundation. This confirms that, in the global world, the struggle for the opportunity to play a leading role in the IFRS Council is considered a priority in order to ensure the protection and to increase the international prestige of the country. This is much more effective than being the leader of a competing using a similar structure [17]. Some other countries adhere to the same strategy. For example, Japan, which, through its representatives in the IFRS management bodies, ensures compliance with the interests of a related capital [18].

Meanwhile, earlier studies noted certain shortcomings in the organization of the IFRS Foundation's activities, including unequal conditions for participating in the standardsetting process in 1995-2007 in terms of geographical representation [19-21]. 
Taking into account the current realities, it is possible to assess the competition for control of the management of the global standardization of financial statements.

Therefore, based on the reviewed literature, it is possible to identify the following provisions, significant for the development of IFRS and the protection of the national interests of the countries participating in this system:

- applied studies of the feasibility of IFRS and their functionality reveal the multifactorial dependence its qualitative characteristics;

- the professional education and the worldview of the specialists involved in the process have a significant impact on the content of the standards;

- the diversity of the composition of contextual factors that determine the national interests of economically developed countries in the field of financial reporting creates the need for active participation in the process of developing international standards, which affect the practical strategies of the respective countries to control this process through the participation of their representatives in the management structures of the IFRS Fund.

Therefore, consideration of the current institutional and financial structure of the IFRS Fund will reveal their impact on the quality and functionality of the standards, which can help to reduce the associated risks of inharmonious development of IFRS. This will also allow an objective assessment of the position of the EEU in the IFRS management system.

\section{Theory and calculations}

The effectiveness of the IFRS Foundation largely depends on the quality of the work of its governing bodies. As of the beginning of 2021, the four highest levels of management of the IFRS Foundation, who were the subjects of this study and formed its base, included 60 people. The analysis is based on the collected data for November 2020.

\section{Analysis of the quantitative characteristics of the IFRS Foundation's regulatory bodies.}

The IFRS Foundation is staffed by highly educated and professionally trained people. According to the data, more than $50 \%$ have a master's degree and more than $32 \%$ have a doctorate mainly in social sciences, and only one person has a different type of industrial education (Table 1).

The largest representations in the Foundation's management are graduates of American (more than 32\%), British (about 12\%), and French (about 7\%) universities.

In the context of increasing political pressure on decisions in global finance, an expansion in the range of universities that provide trained management members and a greater 
involvement of the scientific community in the work of the IFRS Foundation can improve the quality of standards development.

More than $83 \%$ of the management of the IFRS Foundation have practical experience in the field of finance and services. This is more than four times higher than the total representation of the management's experience in other industries from the real economy. The most represented industries include banking (more than 19\%), investment business (more than $8.5 \%$ ), and finance and education (more than 6\% each). The predominance of an industry increases for individual management bodies (Table 2).

This structure correlates with the prevalence of standardization in the financial sector. Industry specifics fall outside the ambit of the International Accounting Standards Board's (IASB) efforts in standards development. This was confirmed by the data from the annual report of the IFRS Foundation for $2020^{3}$.

More than $13 \%$ of the IFRS Foundation's management are professional politicians. Undeniably, for the successful operation of an international organization, it is necessary to consider political factors. However, the politicians represented in the IFRS Foundation carry their own political capital, which may or may not improve the Foundation's involvement in political processes.

Analysis of the IFRS Foundation's activities. An analysis of the financing of the IFRS Foundation's activities identifies three main sources of income. The total revenue from all activities amounted to $£ 30.1$ million $^{4}$ in 2020, and included:

- contributions: $£ 18.1$ million (60\%);

- publications and related activities: $£ 11.7$ million (39\%);

- other income: $£ 0.315$ million (1\%).

The total operating expenses of the fund amounted to $£ 27.4$ million year-on-year. Thus, the independent funding received by the IFRS Foundation was $34 \%$ of the required annual expenses for the maintenance of its current activities as of the end of 2020.

This reveals the lack of financial independence of the IFRS Foundation. This was further confirmed by the structure of voluntary contributions. Of the 140 jurisdictions that use the IFRS to varying degrees, only 32 (23\%) provide contributions. Contributions are made by state authorities (ministries and authorised state bodies) for 14 (10\%) of these jurisdictions. Whereas for the remaining 19 jurisdictions (13\%), revenues come only from non-governmental and business organisations. According to the data of 2020, these funds accounted for $47.99 \%$ of the total contributions received by the IFRS Foundation. Voluntary contributions from the Big 6 to the IFRS Foundation amounted to 12.7\%.

\footnotetext{
${ }^{3}$ IFRS Foundation. Annual Report 2020, pp. 26-27.

URL: https://ifrs.org/content/dam/ifrs/about-us/funding/2020/IFRS-Annual-Report-2020.pdf

${ }^{4}$ Ibid, pp. 13-17.
} 
However, voluntary contributions cannot be considered as a stable source of income. Consequently, the current funding structure could jeopardize the self-sufficiency of the organization.

An analysis of the composition of the jurisdictions that were identified by the management of the IFRS Foundation as permanent payers of voluntary contributions for its statutory activities revealed the asymmetry of their representation in the Foundation. The minimum representation ratio calculated by using Equation (1) based on financial participation was 3.25:

$K=($ Nrep/Scontributions $\cdot 1000000)$

where: Nrep is the number of representatives in the IFRS Foundation's management bodies, and $\Sigma$ contributions represents the total amount of voluntary contributions to finance the IFRS Foundation.

That is, in the IFRS Foundation, the representation of a country with a coefficient value greater than 3.25 is funded by other countries, and the higher the coefficient, the greater the financing required.

An analysis of the representation in the management bodies of the IFRS Foundation at the end of 2020, according to the above criterion, revealed significant imbalances. Thus, the maximum value of the coefficient for countries that are not included in the list of 'founders' of the IFRS Foundation was 1000 000. As shown in Table 3, the highest representation values are associated with Argentina and Turkey (1 000000 each), South Africa (408.16), Brazil (30.3), and New Zealand (12.95). Of the 'founding countries' of the IFRS Foundation, Mexico (1 000 000) and the United States of America (22.67) have the highest financial participation ratios.

Moreover, some countries and state-economic associations globally, such as Russia (contributions to financing amount to 2.32\%) and the Eurasian Economic Union systematically participate in the financing of the activities of the IFRS Foundation to the tune of more than $£ 0.3$ million (the minimum threshold of financial participation is $1.67 \%$ ), and do not have a single representative in its governing bodies. Meanwhile, many countries do not finance the IFRS, but still apply these standards.

To ensure 'social justice', it is advisable to adjust the recruitment process of the management bodies of the IFRS Foundation by accounting for the calculated coefficient. To increase the transparency of the IFRS Foundation's management bodies' formation, it is advisable to use a clear and simple algorithm. One part of the management bodies can be comprised on a competitive basis. The other part, which includes representatives from countries, can be determined by Equation (2), which uses purchasing power parity data:

$($ GDP $X(P P P) /$ World GDP + Population $X /$ World population) $/ 2$. 
The global nature of the spread of the IFRS is incompatible with the organizational and legal form of the IFRS Foundation. This spread was justifiable when the IFRS was developing solely as a pan-European standard. However, the IFRS has outgrown the Foundation's organizational and legal form. A possible solution for minimizing the risks associated with the strengthening of the political component in the activities of the IFRS Foundation and reducing its financial independence may include raising the status of the fund to that of an organization that is part of the United Nations (UN) structure and changing the procedure for financing and forming the management bodies of the IFRS Foundation. The setter of global standards must act as part of a global supranational organization with equal rights and access to the process. Further, it is notable that the main language of these standards is English. Thus, it may take more time for non-Anglosphere members to make decisions about the development of any standards at each stage. Accordingly, the UN has well-developed procedures to handle such issues.

An analysis of the composition of management bodies and the practice of consulting on the application of standards highlighted the problem of amplified participation by the Big 6 (Table 4).

The Big 6 representation in the management bodies is as follows: $27.27 \%$ in The Trustees of the IFRS Foundation, $38.46 \%$ in the IASB, and $64.29 \%$ in the IFRS Interpretations Committee.

These companies certainly have considerable expertise in the application of standards; however, they act as commercial enterprises rather than university research centers. The process of developing and implementing the IFRS entails risks such as the substitution of a professional culture with a corporate culture, monopolization of the field of audit and consulting services, and engendering the differentiation of rights and opportunities of participants in the process.

\section{Results and discussion}

The results of the analysis show that during the long period of development of IFRS.

1. Some shortcomings of the management of the IFRS Foundation, previously noted by researchers, not only have not been eliminated, but also have become deeper and broader. In the significantly changed landscape of international relations, especially in the economic sphere, the neglect of the need to address the identified shortcomings can play a fatal role in the decline of the status and loss of the authority of the Foundation as a global developer of financial reporting standards.

2. The minimal activity of the national authorized bodies of the member states of the EEU in matters of influence in the development of IFRS, by way of defending their national and collective interests in the IFRS Foundation, should be significantly increased. If necessary, by way of forming or reorganizing of institutional structures with adequate 
functionality and an effective system for monitoring the results of their activities. The results allow to formulate proposals for improving IFRS.

The proposals are as follows.

1. To introduce the IFRS Foundation into the system of universally recognized international bodies, under the auspices of the UN. The implementation of this proposal will allow increasing the international credibility and minimizing the risk of the IFRS brand and the geo-political risk. Additionally, it will help in maintaining a high level of financial sovereignty owing to the revision of the structure of financing of current activities by increasing the share of stable financing that is independent of voluntary contributions from commercial structures with unclear aims for the general public.

2. To ensure fair representation of interested countries in the IFRS Foundation's management bodies by using a clear and simple recruitment algorithm with transparent procedures that reduce the risk of its involvement in political processes. The UN recruitment competition approach should maximize scientific, non-political, and nonfinancial industry professionals' access to the management of the Foundation.

3. To increase the variety of industries, practices, and standards. It is necessary to fully consider the industry specifics of the real economy. The increased activity of the development of industry-specific standards can help improve the comparability of the reporting of single-industry companies from different jurisdictions. This could lead to an increase in investment interest in the real sector of the economy and the harmonization of industry development.

4. To make greater use of the potential of academic centers and professional communities for standards development and consulting.

The implementation of the above-mentioned proposals will:

- increase the quality of standards development with the involvement of national research and professional education centers specializing in industrial studies;

- expand the prerequisites for increasing competition in the market of audit and consulting services while preventing domination by the Big 6;

- facilitate closer cooperation of the IFRS Foundation with IFAC and other professional communities.

\section{Conclusion}

In conclusion, while the IFRS Foundation's structure and standards were originally envisaged as global, the actual acquisition of this status imposes additional requirements on the quality of the standards, reinforcing the need to take into account national variations. 
Thus, these global standards require further evolution that accounts for industrial and regional specifics and the interests of all participants and users, which will prevent the risk of forming regional standards. Consequently, the IFRS requires global governance, funding, and approval.

In the interests of ensuring the sustainability of the economic development of the EEU countries, it is advisable to cooperate in efforts to achieve their representation and actively defend their interests in the IFRS Foundation by specialists who have the appropriate training and the necessary competencies. Due to the COVID-19 limitations, the judgments in this study were based on open-source data. This creates a direction for further research in closer cooperation with the IFRS Foundation.

Table 1

Sample data on the professional education of the of the IFRS Foundation's management

\begin{tabular}{lllll}
\hline Field & $\begin{array}{l}\text { Monitoring } \\
\text { Board } \\
\text { (Percentage) }\end{array}$ & $\begin{array}{l}\text { Trustees of the } \\
\text { Foundation } \\
\text { (Percentage) }\end{array}$ & $\begin{array}{l}\text { IASB } \\
\text { (Percentage) }\end{array}$ & $\begin{array}{l}\text { Interpretations } \\
\text { Committee } \\
\text { (Percentage) }\end{array}$ \\
\hline Economics & $3(33.33)$ & $9(47.37)$ & $2(18.18)$ & $1(9.09)$ \\
\hline Business & $3(33.33)$ & $4(21.05)$ & $11(100)$ & $5(45.45)$ \\
\hline Accounting & - & $3(15.79)$ & $2(18.18)$ & $4(36.36)$ \\
\hline Law & $3(33.33)$ & $4(21.05)$ & $1(9.09)$ & - \\
\hline Technology and Industrialization & - & - & - & $1(9.09)$ \\
\hline
\end{tabular}

Source: Authoring, based on the IFRS Foundation data

Table 2

Sample data on the sectoral structure of the previous practical experience of the IFRS Foundation's management

\begin{tabular}{lllll}
\hline Company Activity & $\begin{array}{l}\text { Monitoring } \\
\text { Board } \\
\text { (Percentage) }\end{array}$ & $\begin{array}{l}\text { Trustees of the } \\
\text { Foundation } \\
\text { (Percentage) }\end{array}$ & $\begin{array}{l}\text { IASB } \\
\text { (Percentage) }\end{array}$ & $\begin{array}{l}\text { Interpretations } \\
\text { Committee } \\
\text { (Percentage) }\end{array}$ \\
\hline Regulator & $3(33.33)$ & $10(45.45)$ & $3(23.08)$ & $1(11.11)$ \\
\hline Bank. Investment. Insurance & $2(22.22)$ & $6(27.28)$ & $3(23.08)$ & $3(33.33)$ \\
\hline Audit and Consulting & - & $4(18.18)$ & $5(38.46)$ & $3(33.33)$ \\
\hline Politics & $2(22.22)$ & $1(4.55)$ & - & - \\
\hline Education & $1(11.11)$ & - & $2(15.38)$ & - \\
\hline
\end{tabular}

Source: Authoring, based on the IFRS Foundation data 
Table 3

Maximum calculated values of the representation ratio and financial participation data for countries represented in the IFRS Foundation

\begin{tabular}{lllll}
\hline Country & $\begin{array}{l}\text { Contribution } \\
\text { Amount, } \\
\text { thousand } \mathbf{~}\end{array}$ & $\begin{array}{l}\text { Financial } \\
\text { Contribution, } \\
\text { percentage }\end{array}$ & $\begin{array}{l}\text { Number of } \\
\text { Representatives }\end{array}$ & $\begin{array}{l}\text { Representation } \\
\text { Ratio }\end{array}$ \\
\hline South Africa & 7.35 & 0.04 & 3 & 408.16 \\
\hline Brazil & 132 & 0.72 & 4 & 30.3 \\
\hline USA & 397.051 & 2.15 & 1 & 22.67 \\
\hline New Zealand & 77.219 & 0.42 & 1 & 12.95 \\
\hline Saudi Arabia & 150 & 0.81 & 3 & 6.7 \\
\hline Republic of Korea & 502.776 & 2.73 & 5 & 6 \\
\hline United Kingdom & 828 & 4.49 & 3 & 6 \\
\hline Canada & 534.812 & 2.9 & 5 & 5.6 \\
\hline Japan & 2061.134 & 11.17 & 16 & 2.4 \\
\hline EU, average & 6921.798 & 37.52 & 5 & 2.31 \\
\hline China & 2143.913 & 11.62 & 1 & 2.3 \\
\hline India & 489.5 & 2.65 & 1 & 2 \\
\hline Australia & 561.3 & 3.04 & 1 & 1.8 \\
\hline Argentina & - & - & 1 & 1000000 \\
\hline Mexico & - & - & 60 & 1000000 \\
\hline Turkey & - & 100 & 1000000 \\
\hline Minimum representation & 18450232 & & 3.25 \\
\hline
\end{tabular}

Source: Authoring, based on the IFRS Foundation data

Table 4

Data on the representation of persons related to the top audit companies in the IFRS Foundation's management bodies

\begin{tabular}{llllll}
\hline Management Bodies/BIG 6 & $\begin{array}{l}\text { PwC } \\
\text { (Percentage) }\end{array}$ & $\begin{array}{l}\text { KPMG } \\
\text { (Percentage) }\end{array}$ & $\begin{array}{l}\text { Deloitte } \\
\text { (Percentage) }\end{array}$ & $\begin{array}{l}\text { EY } \\
\text { (Percentage) }\end{array}$ & $\begin{array}{l}\text { BDO } \\
\text { (Percentage) }\end{array}$ \\
\hline Trustees of the Foundation & $2(9.1)$ & $3(13.6)$ & $-(0)$ & $1(4.6)$ & $-(0)$ \\
\hline IAS Board & $2(15.4)$ & $2(15.4)$ & $1(7.7)$ & $-(0)$ & $-(0)$ \\
\hline Interpretations Committee & $3(21.4)$ & $1(7.1)$ & $3(21.4)$ & $1(7.1)$ & $1(7.1)$ \\
\hline
\end{tabular}

Source: Authoring, based on the IFRS Foundation data 


\section{References}

1. Agoglia C.P., Doupnik T.S., Tsakumis G.T. Principles-Based versus Rules-Based Accounting Standards: The Influence of Standard Precision and Audit Committee Strength on Financial Reporting Decisions. The Accounting Review, 2011, vol. 86, no. 3, pp. 747-767. URL: https://doi.org/10.2308/accr.00000045

2. Liang L., Riedl E.J. The Effect of Fair Value versus Historical Cost Reporting Model on Analyst Forecast Accuracy. The Accounting Review, 2014, vol. 89, iss. 3, pp. 1151-1177. URL: https://doi.org/10.2308/accr-50687

3. Kaya D., Kirsch R., Henselmann K. The Role of Non-Governmental Organizations (NGOs) as Intermediaries of the European Union Decision to Adopt International Accounting Standards: 1973-2002. The Accounting Historians Journal, 2016, vol. 43, no. 2, pp. 59-127. URL: http://jstor.org/stable/45120795

4. Baker C.R., Barbu E.M., Le T.N. A Historiographical Review of Research Concerning Accounting Changes in post-Communist Economies. The Accounting Historians Journal, 2015, vol. 42, no. 1, pp. 1-36. URL: http://jstor.org/stable/43487029

5. Bhimani A., Bond D., Sivabalan P. Does Greater User Representation Lead to More User Focused Standards? An Empirical Investigation of IASB's Approach to Standard Setting. Journal of Accounting and Public Policy, 2019, vol. 38, iss. 2, pp. 65-88. URL: https://doi.org/10.1016/j.jaccpubpol.2019.02.004

6. Kadous K., Mercer M. Can Reporting Norms Create a Safe Harbor? Jury Verdicts against Auditors under Precise and Imprecise Accounting Standards. The Accounting Review, 2012, vol. 87, iss. 2, pp. 565-587. URL: http://jstor.org/stable/23245615

7. Helfat C.E. Vertical Firm Structure and Industry Evolution. Industrial Corporate Change, 2015, vol. 24, no. 4, pp. 803-818. URL: https://doi.org/10.1093/icc/dtv027

8. Bajada C. An Examination of the Statistical Discrepancy and Private Investment Expenditure. Journal of Applied Economics, 2001, vol. 4, iss. 1, pp. 27-61. URL: https://doi.org/10.1080/15140326.2001.12040557

9. Preuss S., Königsgruber R. How Do Corporate Political Connections Influence Financial Reporting? A Synthesis of the Literature. Journal of Accounting and Public Policy, 2021, vol. 40, no. 1, Article 106802.

URL: https://doi.org/10.1016/j.jaccpubpol.2020.106802

10.Loughran T., McDonald B. Measuring Readability in Financial Disclosures. The Journal of Finance, 2014, vol. 69, iss. 4, pp. 1643-1671. URL: https://doi.org/10.1111/jofi.12162 
11. Wagenhofer A. Trading off Costs and Benefits of Frequent Financial Reporting. Journal of Accounting Research, 2014, vol. 52, iss. 2, pp. 389-401.

URL: https://doi.org/10.1111/1475-679X.12045

12. Lev B. The Deteriorating Usefulness of Financial Report Information and How to Reverse It. Accounting and Business Research, 2018, vol. 48, iss. 5, pp. 465-493. URL: https://doi.org/10.1080/00014788.2018.1470138

13. Ashbaugh H., Pincus M. Domestic Accounting Standards, International Accounting Standards, and the Predictability of Earnings. Journal of Accounting Research, 2001, vol. 39, no. 3, pp. 417-434. URL: http://jstor.org/stable/2672967

14. Richardson A.J. Merging the Profession: A Social Network Analysis of the Consolidation of the Accounting Profession in Canada. Accounting Perspectives, 2017, vol. 16, iss. 2, pp. 83-104. URL: https://doi.org/10.1111/1911-3838.12139

15. Al Farooque O. Sustainable Financial Reporting Practice in Australian Companies Does Quality Matter? The Journal of Developing Areas, 2016, vol. 50, no. 6, pp. 175-189. URL: http://jstor.org/stable/26415660

16. Riles A. Culture Clash: Experts and the Public, Chapter 4. In: Riles A. (Ed.) Financial Citizenship: Experts, Publics, and the Politics of Central Banking. Ithaca, London, Cornell University Press, 2018, pp. 35-42.

URL: http://jstor.org/stable/10.7591/j.ctv43vr8t.6

17. Camfferman K. International Accounting Standard Setting and Geopolitics. Accounting in Europe, 2020, vol. 17, iss. 3, pp. 243-263.

URL: https://doi.org/10.1080/17449480.2020.1795214

18. Kim J., Koga Y. The Value and Credit Relevance of IFRS versus JGAAP Accounting Information. Hitotsubashi Journal of Commerce and Management, 2020, vol. 53, iss. 1 , pp. 31-48.

URL: https://hermes-ir.lib.hit-u.ac.jp/hermes/ir/re/30974/HJcom0530100310.pdf

19. Jorissen A., Lybaert N., Orens R., Van der Tas L. A Geographic Analysis of Constituents' Formal Participation in the Process of International Accounting Standard Setting: Do We Have a Level Playing Field? Journal of Accounting and Public Policy, 2013, vol. 32, iss. 4, pp. 237-270.

URL: https://doi.org/10.1016/j.jaccpubpol.2013.04.005

20. Larson R.K. Constituent Participation and the IASB's International Financial Reporting Interpretations Committee. Accounting in Europe, 2007, vol. 4, iss. 2, pp. 207-254. URL: https://doi.org/10.1080/17449480701727981 
21.Richardson A.J., Eberlein B. Legitimating Transnational Standard-Setting: The Case of the International Accounting Standards Board. Journal of Business Ethics, 2011, vol. 98, iss. 2, pp. 217-245. URL: https://doi.org/10.1007/s10551-010-0543-9

\section{Conflict-of-interest notification}

I, the author of this article, bindingly and explicitly declare of the partial and total lack of actual or potential conflict of interest with any other third party whatsoever, which may arise as a result of the publication of this article. This statement relates to the study, data collection and interpretation, writing and preparation of the article, and the decision to submit the manuscript for publication. 